Article

\title{
Lipids and Fatty Acids of the White Sea Herring Clupea pallasi marisalbi Berg (Clupeiformes, Clupeidae) from Different Habitats of the White Sea
}

\author{
Svetlana A. Murzina ${ }^{1}{ }^{*}$, Zinaida A. Nefedova ${ }^{1}$, Svetlana N. Pekkoeva ${ }^{1}$, \\ Tatiana R. Ruokolainen ${ }^{1}$, Pauli O. Ripatti ${ }^{1}$, Andrey V. Semushin ${ }^{2}$ and Nina N. Nemova ${ }^{1}$ \\ 1 Institute of Biology, Karelian Research Centre of the Russian Academy of Sciences, \\ Petrozavodsk 185910, Russia; znefed@krc.karelia.ru (Z.A.N.), pek-svetlana@mail.ru (S.N.P.), \\ truok@krc.karelia.ru (T.R.R.), ripatti@bio.krc.karelia.ru (P.O.R.), nemova@krc.karelia.ru (N.N.N.) \\ 2 Knipovich Polar Research Institute of Marine Fisheries and Oceanography (PINRO), \\ Arkhangelsk 163002, Russia; andr@pinro.ru \\ * Correspondence: murzina.svetlana@gmail.com; Tel.: +7-8142-769-810
}

Academic Editor: Jana Pickova

Received: 19 July 2016; Accepted: 21 September 2016; Published: 13 October 2016

\begin{abstract}
Habitation conditions significantly affect the physiological and biochemical state of aquatic organisms, including the balance of lipids that performs important functions in cellular metabolism. The lipid and fatty acid profiles of White Sea herring in Dvina, Kandalaksha, and Onega bays, and in the waters of Tersky Shore (the mouth of the Varzuga River) in autumn (after the fattening period) were studied. Different methods-thin-layer, high-performance liquid and gas chromatography-were used for this purpose. Determined heterogeneity on studied parameters of lipid metabolism of fish from different habitats is associated with differences in trophic and hydrological conditions in these bays. Variations of lipid compositions of herring groups can be a reflection of qualitative and quantitative strategies of biochemical adaptations, aimed at compensating the lipid metabolism of fish under different trophic-ecological conditions of habitation in the White Sea.
\end{abstract}

Keywords: biochemical adaptations; biochemical indicators; ecological monitoring; fatty acids; lipids; the Arctic; White Sea herring

\section{Introduction}

The White Sea herring population, Clupea pallasi marisalbi Berg (Clupeiformes, Clupeidae), is one of the most similar forms to the Pacific herring, Clupea pallasi, and it is one of the most important commercial fish of the White Sea. Local herring herds are confined to certain hydrological conditions in different bays of the sea [1]. Previously, it was thought that White Sea herring from different bays of the White Sea belonged to a single population, a "single biological entity" [2,3]. However, there are other points of view, proponents of which consider that the forms of White Sea herring from different habitats in the sea have different origins [4-6]. It is also supposed that herring are a complex of genetically-isolated forms, related by origin [7]. In recent years, the growth of herring stock has been caused by gradual recovery of White Sea eelgrass, the decline of which happened in 1960 [8,9]. Habitation conditions significantly affect the physiological and biochemical states of aquatic organisms, including the balance of lipids that perform important functions in cellular metabolism. It is known that lipid parameters characterize-to a high degree of accuracy - the functional state of individual species and fish populations as a whole [10-12]. Changing of lipid composition is a part of adaptive reactions that provide the possibility of survival under different combinations of ecological factors (within the limits of optimal oscillations) [10,13]. 
The main aim of the present research was to determinate the lipid and fatty acid profiles of the White Sea herring in Dvina, Kandalaksha, and Onega bays, and in the waters of Tersky Shore (the mouth of the Varzuga River) in autumn (after the fattening period).

\section{Results}

To study the combined effects of two factors-"fish length" $(\mathrm{AB}, \mathrm{cm})$ and "habitat" in the White Sea (complex of ecological environmental factors) on lipid indexes-total lipids, phospholipid, triacylglycerol, cholesterol ester and cholesterol (\% of dry weight) - multifactor analysis of variance was applied. It was shown there was no effect of "fish length" factors on lipid indexes, despite the differences $(p \leq 0.05)$ in size of herring from different capture locations in the White Sea (Table 1). The influence of the "habitat" factor $(p \leq 0.05)$ was mainly determined for all lipid indexes (except for PL). The most notable influence of habitat factor was defined in terms of CHOL-30.1\% ( $p=0.0000)$, TL-19.5\% ( $p=0.0001)$, and TAG-12.6\% ( $p=0.0076)$ (Table 1).

Biochemical analysis revealed that herring caught in the Kandalaksha Bay differed from those of the Dvina and Onega bays and the water area of the Tersky shore by having a higher level of total lipids $(41.7 \% ; 34.5 \% ; 34.5 \% ; 31.8 \%$ and $34.7 \%$ of dry weight, respectively) (Table 1 ).

Among the fish of the Kandalaksha and Onega bays, TAG dominated in the composition of TL (19.4\% and $15.5 \%$ of dry weight, respectively), while, among the herring from Dvina Bay and the Tersky shore, structural PL dominated (19.1\% and $17.2 \%$, respectively). Among the herring from all the areas of the White Sea, the composition of total PL-PC was the largest in terms of quantity (within $10.1 \%-16.1 \%$ of dry weight). It was higher among the fish of Dvina Bay $(p \leq 0.05)$, and it was lower in herring from Onega Bay (Table 2). The content of other individual PL: PI, PS, PEA, LysoPC and SFM, in herring from different habitats, was minor (from $0.15 \%$ to $0.95 \%$ of dry weight); although, in some cases, it was statistically significant $(p \leq 0.05)$. Thus, the herring from the water area of the Tersky Shore, in comparison with other groups, differed by a reduced portion of LysoPC, and, from Dvina Bay, SFM (Table 2).

The content of other structural lipids-CHOL, and its reserve form EsCHOL-among the fish from Kandalaksha Bay and the water area of the Tersky shore-was higher $(p \leq 0.05)$ than among fish from Dvina and Onega bays. At the same time, one of the key indexes of biomembrane microviscosity-CHOL/PL-was significantly higher (0.29) due to CHOL in the groups of herring from the water area of the Tersky shore than among the fish from other bays (0.05-0.19) (Table 1).

Thus, the group of herring from Kandalaksha Bay, which had the highest level of TL (due to reserve TAG), stands out among all the studied groups of White Sea herring, where habit is different in terms of trophoecological conditions. At the same time, in herring from Onega Bay, a reduced level of TL was shown; and among the fish of Dvina Bay, the portion of SFM decreased and the portion of PC increased. The highest index of CHOL/PL was revealed among herring from the water area of the Tersky shore; while in herring from Dvina bay, it was lowest. 
Table 1. Total lipids and lipid classes (\% dry weight) of the White Sea herring, Clupea pallasi marisalbi, collected from different bays of the White Sea.

\begin{tabular}{|c|c|c|c|c|c|c|c|c|c|c|}
\hline $\begin{array}{ll} & \text { Sampling Place } \\
\end{array}$ & Dvina Bay & Kandalaksha Bay & Tersky Shore & Onega Bay & \multicolumn{6}{|c|}{ MANOVA } \\
\hline Number of fish & 20 & 21 & 15 & 25 & \multirow{2}{*}{\multicolumn{2}{|c|}{$p$}} & \multirow{2}{*}{\multicolumn{2}{|c|}{$\%$}} & \multirow{2}{*}{\multicolumn{2}{|c|}{$F$}} \\
\hline Fish length, $\mathrm{cm}$ & $\begin{array}{c}11.9 \pm 0.17^{2,3,4} \\
(10.5-13.0)\end{array}$ & $\begin{array}{c}12.4 \pm 0.13^{1,3,4} \\
(11.0-13.5)\end{array}$ & $\begin{array}{c}11.2 \pm 0.22^{1,2,4} \\
(9.0-12.5)\end{array}$ & $\begin{array}{c}9.98 \pm 0.39^{1,2,3} \\
(8.0-15.0)\end{array}$ & & & & & & \\
\hline \multicolumn{11}{|l|}{$\%$ dry weight } \\
\hline $\mathrm{TL}$ & $34.5 \pm 0.6^{2,4}$ & $41.7 \pm 1.4^{1,3,4}$ & $34.7 \pm 0.8^{2,4}$ & $31.8 \pm 0.8^{1,2,3}$ & 0.7623 & 0.0001 & 12.1 & 19.5 & 0.75 & 8.50 \\
\hline PLs & $19.1 \pm 1.3^{4}$ & $18.4 \pm 1.0^{4}$ & $17.2 \pm 0.8^{4}$ & $14.3 \pm 0.7^{1,2,3}$ & 0.5593 & 0.1608 & 21.4 & 5.9 & 0.93 & 1.78 \\
\hline TAGs & $14.1 \pm 1.2^{2}$ & $19.4 \pm 0.9^{1,3,4}$ & $12.2 \pm 1.0^{2,4}$ & $15.5 \pm 0.9^{2,3}$ & 0.3771 & 0.0076 & 22.0 & 12.6 & 1.10 & 4.39 \\
\hline EfCHOLs & $0.4 \pm 0.1^{2,3}$ & $0.7 \pm 0.1^{1}$ & $0.8 \pm 0.1^{1}$ & $0.5 \pm 0.1$ & 0.3845 & 0.0301 & 26.1 & 10.9 & 1.09 & 3.20 \\
\hline CHOL & $0.9 \pm 0.1^{2,3,4}$ & $3.2 \pm 0.3^{1,3,4}$ & $4.5 \pm 0.9^{1,4}$ & $1.5 \pm 0.1^{1,2,3}$ & 0.9976 & 0.0000 & 6.3 & 30.1 & 0.31 & 10.57 \\
\hline CHOL/PLs & $0.05 \pm 0.01^{2,3,4}$ & $0.19 \pm 0.03^{1,4}$ & $0.29 \pm 0.08^{1,4}$ & $0.11 \pm 0.01^{1,2,3}$ & - & - & - & - & - & - \\
\hline
\end{tabular}

Data means mean \pm standard deviation for length of fish $-\mathrm{m} \pm \mathrm{m}$ (min-max). ${ }^{1}$ Indicates significant differences $(p \leq 0.05)$ in comparison to fish from Dvina Bay; ${ }^{2}$ indicates significant differences $(p \leq 0.05)$ in comparison to fish from Kandalaksha Bay; ${ }^{3}$ indicates significant differences $(p \leq 0.05)$ in comparison to fish from the Tersky Shore; and ${ }^{4}$ indicates significant differences $(p \leq 0.05)$ in comparison to fish from Onega Bay. TL: total lipids; PL: phospholipids; TAG: triacylglycerols; EfCHOL: cholesterol esters. 
Table 2. Total phospholipids and individual phospholipids classes (\% dry weight) of the White Sea herring Clupea pallasi marisalbi, collected from different bays of the White Sea.

\begin{tabular}{ccccc}
\hline Sampling Place/Parameter & Dvina Bay & Kandalaksha Bay & Tersky Shore & Onega Bay \\
\hline Number of Fish & $\mathbf{2 0}$ & $\mathbf{2 1}$ & $\mathbf{1 5}$ & $\mathbf{2 5}$ \\
\hline PLs & $19.1 \pm 1.3^{4}$ & $18.4 \pm 1.0^{4}$ & $17.2 \pm 0.8^{4}$ & $14.3 \pm 0.7^{1,2,3}$ \\
PI & $0.52 \pm 0.08$ & $0.68 \pm 0.05^{3,4}$ & $0.38 \pm 0.04^{2}$ & $0.43 \pm 0.03^{2}$ \\
PS & $0.80 \pm 0.15$ & $0.79 \pm 0.10^{4}$ & $0.64 \pm 0.07$ & $0.54 \pm 0.04^{2}$ \\
PEA & $0.59 \pm 0.11$ & $0.82 \pm 0.07$ & $0.85 \pm 0.10$ & $0.62 \pm 0.12$ \\
PC & $16.06 \pm 1.07^{2,3,4}$ & $13.39 \pm 0.78^{1,4}$ & $12.93 \pm 0.84^{1,4}$ & $10.11 \pm 0.55^{1,2,3}$ \\
LysoPC & $0.55 \pm 0.12^{2,3,4}$ & $1.44 \pm 0.13^{1,3}$ & $0.25 \pm 0.02^{1,2,4}$ & $1.28 \pm 0.14^{1,3}$ \\
SFM & $0.15 \pm 0.05^{2,3,4}$ & $0.54 \pm 0.08^{1,4}$ & $0.95 \pm 0.23^{1}$ & $0.95 \pm 0.12^{1,2}$ \\
Unidentified & $0.39 \pm 0.10^{3}$ & $0.75 \pm 0.18^{4}$ & $1.20 \pm 0.25^{1,4}$ & $0.41 \pm 0.06^{2,3}$ \\
\hline
\end{tabular}

PLs: phospholipids; PI: phosphatidylinositol; PS: phosphatidylserine; PC: phosphatidylcholine; PEA: phosphatidylethanolamine; LysoPC: lysophosphatidylcholine; and SFM: sphingomyelin. ${ }^{1}$ Indicates significant differences $(p \leq 0.05)$ in comparison to fish from Dvina Bay; ${ }^{2}$ indicates significant differences $(p \leq 0.05)$ in comparison to fish from Kandalaksha Bay; ${ }^{3}$ indicates significant differences $(p \leq 0.05)$ in comparison to fish from the Tersky Shore; and ${ }^{4}$ indicates significant differences $(p \leq 0.05)$ in comparison to fish from Onega Bay.

The discriminant analysis of White Sea herring, inhabiting different areas of the White Sea, where the main classes of lipids-PL, TAG, EsCHOL and CHOL-were selected as variables, allowed to divide the studied groups of herring in accordance with three discriminant functions. The first function determined $63 \%$ of variability of the studied objects (Wilks' lambda $\lambda=0.27, p=0.0000$ ), the second function determined 29\% $(\lambda=0.58, p=0.0000)$, and the third determined $8 \%(\lambda=0.88, p=0.0071)$. When location of the research objects was in the space of the first and second discriminant functions (Figure 1), two groups-the herring of the Kandalaksha Bay and the Tersky shore-which slightly transgress with each other, clearly stood out.

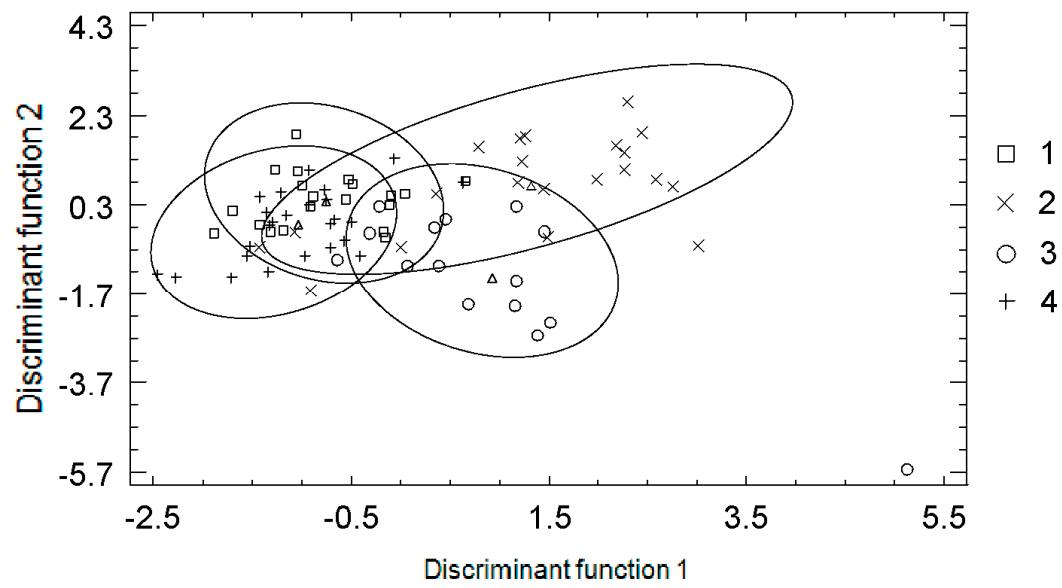

Figure 1. Discriminant analysis of the White Sea herring from different areas of the sea on contents of PLs (phospholipids), TAGs (triacylglycerols), EfCHOL (cholesterol esters), CHOL (cholesterol) in the cloud of two main discriminant functions. 1-herring from Dvina Bay, 2-herring from Kandalaksha Bay, 3-herring from Tersky Shore, 4-herring from Onega Bay. Ovals mean the density, location between two axes (strength of factor), and overlap of fish from different biotopes on studied lipid parameters.

The groups of herring from the Onega and Dvina bays showed a strong joint transgression. The first function was formed by CHOL (load: 0.85), PL (load: 0.79), TAG (load: 0.59), and EsCHOL (load: 0.46), which demonstrated and determined the direction of fish variability in terms of the qualitative and quantitative content of lipid classes-primarily structural. The second function was characterized by a significant contribution of TAG (factor load: 0.94) and PL (load: 0.62), which were 
opposed by ESCHOL (load: 0.10) and CHOL (load: 0.44). This result confirmed the conclusions of the biochemical analysis regarding different quantitative compositions of energetic and structural lipids in the groups of herring from different habitats of the sea. The third dispersion function indicated the direction and speed of energetic and structural metabolism, which was evidenced by the factor load of TAG (0.38), and made the greatest contribution to the formation of this axis, and opposed the factor load of PL $(-0.71)$.

In the fatty acid profile of TL of White Sea herring in the fish groups from all studied areas, MUFA (monounsaturated) dominated (from $38.8 \%$ to $42.1 \%$ of total FA) in fish studied collected from all sites, among which 18:1(n-9) and 16:1(n-7) FA (within the limits of $18.9 \%-20.1 \%$ and $7.73 \%-11.5 \%$ of total FA, respectively) prevailed (Table 3). The fish from Kandalaksha Bay had increased $(p \leq 0.05)$ content of 18:1(n-9) FA in relation to those of the Tersky shore and Onega Bay. At the same time, the herring from Onega Bay differed by a low $(p \leq 0.05)$ level of 16:1(n-7) FA. It was determined that the amount of other MUFA-18:1(n-7), 20:1(n-9), 22:1(n-11), 22:1(n-7), 24:1(n-9)—did not exceed 5.0\% of total FA, but it significantly $(p \leq 0.05)$ differed in groups from different habitats. In the herring groups of the compared habitats, variations with minor specific FA, 20:1(n-9) and 22:1(n-11), 22:1(n-7), and 24:1(n-9), require additional studies (Table 3).

Table 3. Fatty acids profile (\% sum of FAs) of the White Sea herring Clupea pallasi marisalbi collected from different bays of the White Sea.

\begin{tabular}{|c|c|c|c|c|}
\hline Fatty Acids/Sampling Place & Dvina Bay & Kandalaksha Bay & Tersky Shore & Onega Bay \\
\hline Number of Fish & 20 & 21 & 15 & 25 \\
\hline $14: 0$ & $10.53 \pm 0.35^{2,4}$ & $12.40 \pm 0.28^{1,3,4}$ & $11.01 \pm 0.20^{2,4}$ & $8.80 \pm 0.43^{1,2,3}$ \\
\hline $16: 0$ & $21.66 \pm 0.47^{3}$ & $21.40 \pm 0.35^{3}$ & $20.43 \pm 0.23^{1,2,4}$ & $22.26 \pm 0.62^{3}$ \\
\hline $17: 0$ & $0.47 \pm 0.06^{3,4}$ & $0.37 \pm 0.06^{4}$ & $0.31 \pm 0.01^{1,4}$ & $0.90 \pm 0.02^{1,2,3}$ \\
\hline 18:0 & $2.25 \pm 0.06^{2,4}$ & $1.66 \pm 0.07^{1,3,4}$ & $2.10 \pm 0.01^{2,4}$ & $3.21 \pm 0.17^{1,2,3}$ \\
\hline$\Sigma$ SFA & $37.12 \pm 0.80$ & $37.23 \pm 0.66^{3}$ & $35.23 \pm 0.33^{2}$ & $37.26 \pm 0.81$ \\
\hline $16: 1(n-9)$ & $0.73 \pm 0.06$ & $0.40 \pm 0.04^{3,4}$ & $0.68 \pm 0.02^{2}$ & $0.74 \pm 0.10^{2}$ \\
\hline $16: 1(n-7)$ & $11.31 \pm 0.29^{4}$ & $11.45 \pm 0.22^{4}$ & $11.11 \pm 0.23^{4}$ & $7.73 \pm 0.24^{1,2,3}$ \\
\hline $17: 1(n-7)$ & $0.35 \pm 0.04^{4}$ & $0.34 \pm 0.04^{4}$ & $0.40 \pm 0.03^{4}$ & $0.59 \pm 0.03^{1,2,3}$ \\
\hline $18: 1(n-9)$ & $19.80 \pm 0.35$ & $20.14 \pm 0.33^{3,4}$ & $18.86 \pm 0.25^{2}$ & $18.40 \pm 0.73^{2}$ \\
\hline $18: 1(n-7)$ & $4.05 \pm 0.28^{2,4}$ & $3.19 \pm 0.26^{1}$ & $3.62 \pm 0.06$ & $3.39 \pm 0.10^{1}$ \\
\hline $18: 1(n-5)$ & $0.82 \pm 0.05^{2,3,4}$ & $1.09 \pm 0.05^{1,4}$ & $1.07 \pm 0.05^{1,4}$ & $0.69 \pm 0.03^{1,2,3}$ \\
\hline $20: 1(n-11)$ & $0.24 \pm 0.05$ & $0.17 \pm 0.02$ & $0.26 \pm 0.06$ & $0.58 \pm 0.24$ \\
\hline $20: 1(n-9)$ & $1.46 \pm 0.12^{2,3}$ & $2.10 \pm 0.21^{1}$ & $2.50 \pm 0.22^{1}$ & $1.93 \pm 0.56$ \\
\hline $22: 1(n-9)$ & $0.32 \pm 0.02$ & $0.32 \pm 0.02$ & $0.37 \pm 0.02$ & $0.79 \pm 0.42$ \\
\hline $22: 1(n-7)$ & $0.23 \pm 0.01^{3,4}$ & $0.21 \pm 0.01^{4}$ & $0.20 \pm 0.01^{1,4}$ & $0.43 \pm 0.03^{1,2,3}$ \\
\hline $24: 1(n-9)$ & $0.22 \pm 0.08^{4}$ & $0.27 \pm 0.08^{3,4}$ & $0.04 \pm 0.00^{2,4}$ & $1.18 \pm 0.04^{1,2,3}$ \\
\hline$\Sigma$ MUFA & $41.40 \pm 0.75$ & $42.06 \pm 0.51$ & $41.77 \pm 0.49$ & $38.81 \pm 1.57$ \\
\hline $16: 3(n-6)$ & $0.35 \pm 0.03^{2,4}$ & $0.21 \pm 0.03^{1,3,4}$ & $0.37 \pm 0.01^{2,4}$ & $0.01 \pm 0.00^{1,2,3}$ \\
\hline $18: 2(n-6)$ & $1.31 \pm 0.05^{3,4}$ & $1.21 \pm 0.02^{3,4}$ & $1.50 \pm 0.06^{1,2,4}$ & $1.06 \pm 0.05^{1,2,3}$ \\
\hline $18: 3(n-6)$ & $0.15 \pm 0.01^{2,3}$ & $0.11 \pm 0.01^{1,3,4}$ & $0.09 \pm 0.01^{1,2,4}$ & $0.15 \pm 0.01^{2,3}$ \\
\hline $20: 4(n-6)$ & $0.28 \pm 0.02^{3}$ & $0.30 \pm 0.01^{3}$ & $0.37 \pm 0.01^{1,2,4}$ & $0.29 \pm 0.02^{3}$ \\
\hline$\Sigma(n-6)$ PUFA & $3.52 \pm 0.16^{2,4}$ & $2.70 \pm 0.07^{1,3}$ & $3.50 \pm 0.11^{2,4}$ & $2.58 \pm 0.09^{1,3}$ \\
\hline $18: 3(n-3)$ & $0.76 \pm 0.06^{2}$ & $0.92 \pm 0.03^{1,3}$ & $0.74 \pm 0.03^{2,4}$ & $0.93 \pm 0.07^{3}$ \\
\hline $20: 5(n-3)$ & $6.51 \pm 0.52$ & $6.61 \pm 0.31$ & $6.78 \pm 0.38$ & $7.38 \pm 0.47$ \\
\hline $22: 6(n-3)$ & $5.25 \pm 0.45^{3,4}$ & $5.11 \pm 0.27^{3,4}$ & $6.53 \pm 0.18^{1,2}$ & $7.01 \pm 0.65^{1,2}$ \\
\hline$\Sigma(n-3)$ PUFA & $15.12 \pm 1.15^{4}$ & $15.84 \pm 0.68^{4}$ & $17.06 \pm 0.49$ & $19.19 \pm 1.35^{1,2}$ \\
\hline$\Sigma$ PUFA & $21.48 \pm 1.38$ & $20.71 \pm 0.74^{3}$ & $23.0 \pm 0.50^{2}$ & $23.92 \pm 1.48$ \\
\hline$(n-3) /(n-6)$ & $4.29 \pm 0.02^{2,4}$ & $5.86 \pm 0.01^{1,3,4}$ & $4.87 \pm 0.01^{2,4}$ & $7.44 \pm 0.01^{1,2,3}$ \\
\hline $18: 3(n-3) / 18: 2(n-6)$ & $0.58 \pm 0.04^{2,4}$ & $0.76 \pm 0.02^{1,3,4}$ & $0.50 \pm 0.02^{2,4}$ & $0.89 \pm 0.05^{1,2,3}$ \\
\hline $16: 0 / 18: 1(n-9)$ & $1.10 \pm 0.31^{4}$ & $1.07 \pm 0.27^{4}$ & $1.08 \pm 0.32^{4}$ & $1.24 \pm 0.05^{1,2,3}$ \\
\hline
\end{tabular}

The amounts of 12:0, 15:0, 20:0, 24:0, 14:1(n-5), 16:1(n-5), 20:1(n-7), 22:1(n-11), 16:2(n-9), 18:2(n-9), 20:2(n-9), 22:2(n-9), 16:2(n-7), 16:2(n-6), 20:2(n-6), 18:4(n-3), and 20:4(n-3) FAs were minor and are not present in the table. ${ }^{1}$ Indicates significant differences $(p \leq 0.05)$ in comparison to fish from Dvina Bay; ${ }^{2}$ indicates significant differences $(p \leq 0.05)$ in comparison to fish from Kandalaksha Bay; ${ }^{3}$ indicates significant differences $(p \leq 0.05)$ in comparison to fish from the Tersky Shore; and ${ }^{4}$ indicates significant differences $(p \leq 0.05)$ in comparison to fish from Onega Bay. 
It was noted that, in the composition of TL of White Sea herring of all groups, the proportion of SFA was high (35.2\%-37.3\% of total FA), mainly due to $16: 0$ and 14:0 FA-the levels of which were in the range of $20.4 \%-22.3 \%$ and $8.8 \%-12.4 \%$ of total FA, respectively. Low content of 18:0 FA $(1.66 \%-3.21 \%$ of total FA) was noted in fish from all water areas (Table 3$)$.

In White Sea herring, the content of total PUFA (polyunsaturated fatty acids) was in the range of $20.7 \%-23.9 \%$ of total FA, mainly due to FA of the (n-3) family $(15.1 \%-19.2 \%$ of total FA) with a dominance of FAs 20:5(n-3) and 22:6(n-3). The herring from Onega Bay differed slightly, but significantly $(p \leq 0.05)$, by a high level of these acids, and indexes of $(n-3) /(n-6)$ PUFA, 18:3(n-3)/18:2(n-6), and 16:0/18:1(n-9) (Table 3).

Discriminant analysis of White Sea herring, inhabiting different places of the White Sea, was carried out in terms of the content of 11 fatty acids of total lipids-14:0, 16:0, 18:0, 16:1(n-7), 18:1(n-9), 18:1(n-7), 20:1(n-9), 18:2(n-6), 20:4(n-6), 18:3(n-3), and 22:6(n-3). It was defined that these fatty acids allowed determining a 95\% accuracy, which, of the studied groups, this research object belongs to. The first discriminant function ( $73 \%$ of total variability, $\lambda=0.02, p=0.0000$ ) enables to select a group of herring from Onega Bay, which was characterized by maximal (for 18:0 and 22:6(n-3) FA) and minimal (for 16:1(n-7) FA) values (Figure 2, Table 3).

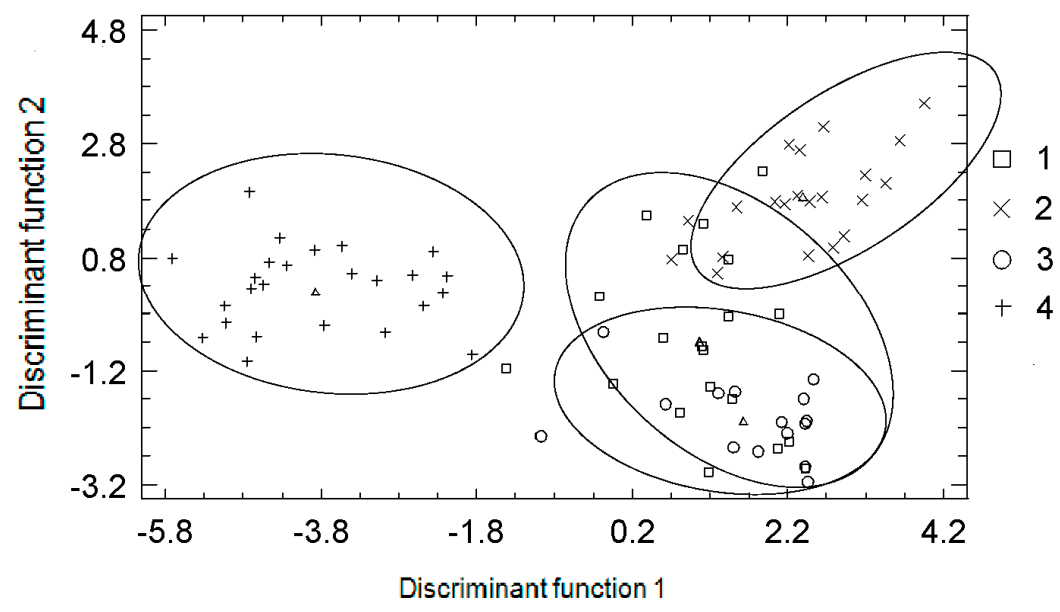

Figure 2. Discriminant analysis of White Sea herring from different areas of the sea, based on the contents of 11 fatty acids-14:0, 16:0, 18:0, 16:1(n-7), 18:1(n-9), 18:1(n-7), 20:1(n-9), 18:2(n-6), 20:4(n-6), 18:3(n-3), and 22:6(n-3), in the areas of the two main discriminant functions. 1-herring from Dvina Bay, 2-herring from Kandalaksha Bay, 3-herring from the Tersky Shore, 4-herring from Onega Bay. Ovals mean the density, location between two axes (strength of factor) and overlap of fishes from different biotopes on studied fatty acids.

These FAs made the most significant contributions to the formation of the first discriminant function. The second discriminant function (19\% of total variability, $\lambda=0.19, p=0.0000)$ allows to select herring from Kandalaksha and Dvina bays and the Tersky shore. The herring from Dvina Bay showed uniform dissemination in a wide range, and mixing with herring from the Tersky Shore of the White Sea (Figure 2). The second discriminant axis is formed mainly by 18:2(n-6) and 18:3(n-3) FA, which have opposite factor loads: -1.15 and 1.75, respectively-the opposite correlation. Only $9 \%$ $(\lambda=0.54, p=0.0000)$ refer to the third discriminant function. It was formed by the following FA: 18:1(n-9), 20:1(n-9), 20:4(n-6), and 22:6(n-3), which were opposed by 16:1(n-7), 18:1(n-7), 18:2(n-6), and 18:3(n-3). This was reasonably explained by the heterogeneity of ecological, particularly trophic, conditions in different habitats of the White Sea.

Thus, White Sea herring, from all the studied catch locations in the White Sea, were characterized by high levels of total MUFA ( $p \geq 0.05)$. The fish from Onega Bay were distinguished from the others in terms of variations of individual FA: With high contents of 17:0, 18:0, 17:1(n-7), 22:1(n-7), 24:1(n-9), 18:2(n-7), 22:6(n-3), and reduced contents of 14:0, 16:1(n-7), 18:1(n-5), 16:3(n-6), and 18:2(n-6). 
In addition to this, this group was characterized by high ratios of (n-3)/(n-6) PUFA, 18:3(n-3)/18: $3(n-6)$, and 16:0/18:1(n-9).

\section{Discussion}

The results of multifactor analyses of variance show that, as a factor in these conditions, "fish length" has no significant effect on the lipid spectrum of White Sea herring. It is the "habitat", and more exactly, a complex of abiotic and biotic factors that have direct and indirect effects on the formation of differences in terms of lipid status groups inhabiting various places of the White Sea.

\subsection{Total Lipids and Their Classes}

A complex of factors, among which ecological factors-temperature regime and food base-play a leading role, influences the processes of accumulation and consumption of lipids, mainly TAG (storage lipids) in fish [13-15]. The high content of TAG in the herring (especially from Kandalaksha Bay) during feeding season (autumn) indicates that food-supply accumulation of energy reserves [13] is especially important for their overwintering. It is known that the hydrological conditions of Kandalaksha Bay contribute to intensive development of plankton. The biomass produced by planktonic bacteria in July-September is characterized by a maximal value [16]. Therefore, this bay is defined by considerable diversity and high levels of productivity of bacteria and phytoplankton, which are valuable food objects for herring and provides high levels of storage lipids.

Specific hydrological conditions connected with the income of large amounts of fresh water from rivers, the presence of strong reversing tidal currents, and significant fluctuations of temperature, salinity, transparency and water color-especially in a warm-up period, develop in different parts of the relatively shallow-waters of Onega Bay [17-19]. As a result, different conditions can form for all organisms in the areas that are close to the bay.

The content of TAG and PL was lower among the fish of Onega Bay than among the herring from Kandalaksha Bay. The TAG/PL ratio was the same. According to Reference [20], absolute and relative contents are less important than the ratio of individual lipid classes. It may be considered that, in case of different levels of structural and storage lipids in fish in Kandalaksha and Onega bays, comparatively favorable conditions form for groups of herring during the feeding period.

\subsection{Membrane Lipids}

Among the herring from all of the studied water areas of the White Sea, the dominance of PC was determined. Among the lipids, this PL was the most significant in terms of quantity among different species of fish [21,22]. The greatest variations of concentration are found in relation to PC and minor PL (LysoPC, SFM), depending on herring habitat. These membrane PLs perform specific regulatory functions that depend on their concentration, and have a modulating effect on the activity of membrane-bound enzymes, in accordance with the living conditions of organisms $[23,24]$. Changing of the level of minor LysoPC and SFM cell membranes takes place under the influence of external signals (for example, fluctuation of temperature, salinity, and other stressful effects of the environment) $[23,25]$.

According to the data of the discriminant analysis, the main factor load relates to CHOL. Using biochemical and discriminant methods, it was determined that CHOL levels in the herring from Kandalaksha Bay and the water area of the Tersksy Shore were maximal, while among the herring from the Dvina and Onega bays, it was minor. The revealed quantitative differences of CHOL and $\mathrm{CHOL} / \mathrm{PL}$ ratio in the groups of herring from different habitats of the White Sea can be associated with different functional activities of the membrane lipids of fish, which are subject to a number of processes: Their intake of food; enhanced synthesis in the liver; modification of biomembranes of cells; and increasing or reducing of physiological functions (motion activity at different rates of flow, turbulence degree, pressure, environmental temperature, etc.). Variations in relation to CHOL and $\mathrm{CHOL} / \mathrm{PL}$ ratios among the herring groups are one of the ways of regulating the state (fluidity) of cellular membranes in the process of the adaptation of organisms to changing environmental 
conditions. It is known that enhancement of cholesterol biosynthesis in the liver, as well as in the case of intake in food, is accompanied by acceleration of its esterification [26], which was shown in our research of the herring from Kandalaksha Bay and the water area of the Tersksy Shore, and may reflect an adaptive response to excessive intake of CHOL.

\subsection{Fatty Acids}

It is known that FA components of lipids are the most labile and are involved in the process of the development of adaptive responses [27-29]. One of the characteristics of FA composition of aquatic organisms of the northern latitudes is a high level of MUFA. In all of the groups of herring from the studied habitats of the White Sea, the prevalence of MUFA due to 18:1(n-9) and 16:1(n-7) was revealed. It is known that MUFA are food borne and they are biomarkers for specific groups of aquatic organisms: 18:1(n-9) FA—the main biomarker of dinophytes (Dinophyta division, Dinophyceae class) and bacterial plankton; and 16:1(n-7) FA—diatom (Ochrophyta division, Bacillariophyceae class) microalgae [30-32]. Dinophytes and diatom microalgae are major contributors to the White Sea phytoplankton biomass [16]. The levels of production of phytoplankton vary considerably in different habitats of the White Sea; they also change depending on seasons and years. According to the literature, in the Kandalaksha Bay, the biomass produced by planktonic bacteria is maximal in July-September. By the beginning of autumn (mid-August) in the White Sea, the complex of planktonic algae develops-where, at first, large dinophytes and then diatoms dominate. At the end of October (sampling time), the period of phytoplankton growth finishes and, in water, there are only large species of dinophytes and diatoms that completely disappear [33]. Apparently, this explains the low level of 16:1(n-7) FA among the herring in Onega Bay in comparison to the fish from other catch areas.

In the groups of herring from all the habitats of the sea, minor MUFA, individually, did not exceed $4.1 \%$ of total FA: $18: 1(n-7)$ FA is synthesized (up to $53.6 \%$ ) by green (Chlorophyta division, Chlorophyceae class) algae: 20:1(n-9) and 22:1(n-11) FA are synthesized de novo by only phytovorous species of Calanus ssp. [32,34]. In the formation of the zooplankton community, the Copepoda order plays a main role. Almost everywhere, they form the basis of biomass in the White Sea $[35,36]$.

Relatively high content of SFA and 16:0 and 14:0 FA prevailing in fish is connected not only with synthesis de novo, but also with their accumulation due to consumption of phytoplankton and zooplankton, the presence and availability of which, in the food chains of the herring from various areas of the White Sea, differed. Low levels of 14:0 and 16:1(n-7) FA in the herring of Onega Bay, in comparison with those from other habitats, is possibly associated with the decrease of the productivity of diatoms in this period of biomarkers, of which they are. An index of 16:0/18:1(n-9) FA was higher among the herring of Onega Bay, which indicates a higher degree of intensity of lipid metabolism [37].

Low content of PUFA, especially 22:6(n-3) FA among White Sea herring, in comparison with other Arctic and sub-Arctic species of fish, indicates that these FA were not the factor in the functioning of biomembranes under these conditions. The ratio (n-3)/(n-6) PUFA plays a particular role due to competitive relations in the process of their metabolism [38]. In relation to the herring from Onega Bay, the ratio of $(n-3) /(n-6)$ PUFA was higher than in the fish groups of other habitats. Changing of the degree of unsaturation of lipids is a common mechanism of regulation of activity of membrane enzymes under the conditions of fluctuation of environmental factors [29,39]. As a result of the application of discriminant analysis, it was shown that one of the directions of White Sea herring variability, and its division into groups, was formed by 18:2(n-6) and 18:3(n-3) FA (the second discriminant function).

In herring in various tropho-ecological conditions, high levels of particular FA varied within certain limits and depended mainly on the temperature and food regimes in this period of life. Determined fatty acid spectra of White Sea herring from different habitats of the White Sea indicate that the main source of food in the feeding period (October) was representative of diatoms and dinophytes, and the proportion of copepods was insignificant. 


\section{Materials and Methods}

The White Sea herring adults (females) were collected in autumn in Dvina $\left(64^{\circ} 57^{\prime}, 38^{\circ} 23^{\prime}\right)$, Kandalaksha $\left(67^{\circ} 02^{\prime}, 32^{\circ} 23^{\prime}\right)$, and Onega bays $\left(64^{\circ} 59^{\prime}, 36^{\circ} 37^{\prime}\right)$ and in waters of the Tersky Shore of the White Sea, at depths of 50, 25 and 38 meters, and at temperatures of $6.5,2.9$ and $6.7^{\circ} \mathrm{C}$, respectively, according to the method described in Reference [40]. In total, 66 individual specimens $(n)$ were analyzed. Characteristics, specifics, and geographical coordinates of sampling areas are presented in Table 4.

Table 4. Characteristics of sampling areas in the White Sea.

\begin{tabular}{ccccc}
\hline Characteristic/Sampling & Dvina Bay & Kandalaksha Bay & Tarsky Shore & Onega Bay \\
\hline Coordinates & $64^{\circ} 57^{\prime}$ & $67^{\circ} 02^{\prime}$ & $66^{\circ} 10^{\prime}$ & $64^{\circ} 59^{\prime}$ \\
Depth, $\mathrm{m}$ & $38^{\circ} 23^{\prime}$ & $32^{\circ} 23^{\prime}$ & $37^{\circ} 03^{\prime}$ & $36^{\circ} 37^{\prime}$ \\
Water temperature, ${ }^{\circ} \mathrm{C}$ & 50.0 & 25.0 & 38.0 & 38.0 \\
Salinity, $\% 0$ & 6.5 & 2.9 & 5.9 & 6.7 \\
\hline
\end{tabular}

The flesh of the fish was homogenized and fixed in a solvent system of chloroform:methanol $(2: 1, v / v)$. Samples were homogenated individually in glass vials and kept in a cold room at $4{ }^{\circ} \mathrm{C}$. Total lipids (TL) were extracted by the method described in Reference [41]. The dry weights, recovered after the lipid extraction of the tissues, were dried over phosphoric anhydride until the samples reached a constant weight.

The lipid classes, such as PLs, TAGs, cholesterols (CHOL), wax esters and cholesterol esters $(\mathrm{WE}+\mathrm{CE})$, as one fraction, were analyzed using thin-layer chromatography. PLs, TAGs and WE + CE were quantified using spectophotometery [42], following the method of Sidorov [43], and CHOL by the method used in Reference [44]. In this research, we use a SF-2000 spectrophotometer (OKB Spectr, St. Petersburg, Russia) at a wave length of 540 and $50 \mathrm{~nm}$, respectively. To identify the lipid classes on the plates, standards (Sigma Aldrich, St. Louis, MO, USA) for thin-layer chromatography were used.

High-performance liquid chromatography (HPLC, Stayer, AKVILON, Moscow, Russia) was used to identify six phospholipids: phosphatidylserine, phosphatidylethanolamine, phosphatidylinositol, phosphatidylcholine, lysophosphatidylcholine, and sphingomyelin following the method used in Reference [45]. Nucleosil 100-7 column with an acetonitrile:hexane:methanol:phosphorus acid (918:30:30:17.5 by volume) mobile phase was applied, and the detection was at a wave length of $206 \mathrm{~nm}$ (UV light). Phospholipid standards (Supelco-Analytical, Bellefonte, PA, USA) were used for the identification and quantification of the phospholipid compounds in the sample.

To analyze the fatty acid composition of the total lipid extracts, gas-liquid chromatography was used. Fatty acids were converted to fatty acid methyl esters (FAME) and were identified using a "Chromatec-Crystal-5000.1" (Yoshkar-Ola, Russia) gas chromatograph with a flame-ionization detector. A Zebron capillary gas chromatographic column (Phenomenex, Torrance, CA, USA) was installed into a chromatograph, and an isothermal column configuration was used $\left(205{ }^{\circ} \mathrm{C}\right)$; the temperature of the detector and evaporator were 250 and $240{ }^{\circ} \mathrm{C}$, respectively. The internal standard was 22:0 FA. Chromatec-Analytik-5000.1 software, version 2.6 (Yoshkar-Ola, Russia), was used for recording and interpreting the data. Standard mixtures of Supelco 37 FAME mix (Supelco-Analytical). We compared the equivalent the length of carbon chain and table constants, according to Jamieson [46].

The research was carried out using the equipment of the environmental biochemistry laboratory and the facilities of the Equipment Sharing Centre of the Institute of Biology, KarRC of RAS-“Multidisciplinary Basic and Applied Research on the Functioning of Living Systems in the North".

The data were analyzed to determine whether they exhibited a normal distribution. The significance of data differences was assessed using one-way analysis of variance (ANOVA). Multifactor analysis of variance (MANOVA) was used to study the influence of two characteristics: "fish length" (AB, cm) and "habitat" (complex of ecological factors) on total lipids; and phospholipids, 
triacylglycerol, cholesterol, and cholesterol esters (\% of dry weight). Differences were considered significant at $p \leq 0.05$. In the study, StatGrafics 2.5 software, Excel, and Stadia statistical packages were used.

Differences in lipid and fatty acid content between the groups of White Sea herring, inhabiting different parts of the White Sea, were determined using the discriminant analysis, where four lipid parameters: Phospholipid, triacylglycerol, cholesterol ester and cholesterol (\% of dry weight), and 11 indexes of fatty acids-14:0, 16:0, 18:0, 16:1(n-7), 18:1(n-9), 18:1(n-7), 20:1(n-9), 18:2(n-6), 20:4(n-6), 18:3(n-3), and 22:6(n-3) (\% of total FA) were chosen as variables. As a method of multivariate statistics, the discriminant analysis allows to determine differences between groups of objects that differ in terms of a number of characteristics. It also makes it possible to define whether an object belongs to a particular group [47]. The analysis shows which variables make the most significant contribution to the separation of objects into groups, and how accurate the selected characteristics are for further analysis of such samples.

\section{Conclusions}

The evaluation of lipid and fatty acid status of White Sea herring, Clupea pallasi maris albi Berg (Clupeiformes, Clupeidae), from different bays of the White Sea (Dvina, Kandalaksha, and Onega), as well as the water area of the Tersksy Shore of the sea basin (the mouth of the Varzuga River) were carried out in autumn. The group of herring inhabiting Kandalaksha Bay, which had a high lipid status (due to content of storage TAG), stands out. In the herring from Onega Bay, a low level of total lipids, including PL, was defined. Discriminant analysis identified two subgroups of herring, in the Dvina and Onega bays, which differed in terms of level of total lipids and PLs from Kandalaksha Bay, in terms of total lipids, TAG, and CHOL. Previous studies have shown that polar lipids have strong anti-inflammatory properties [48]. Inflammation is a trigger phenomenon for a vast array of diseases, including Cardiovascular Diseases (CVDs), cancer, and stroke. Hence, food with high levels of polar lipids are regarded as beneficial against the onset of these diseases [49].

Shown differences in lipid and fatty acid spectrums in the groups of herring from compared habitats of the White Sea can be explained by different trophic, mainly, ecological conditions in the studied cites. At the same time, the influence of genetic factors is not excluded. Defined lipid status is the most indicative criteria, reflecting the physiological state of individual specimens and groups as a whole. Variations of lipid composition in herring groups can be a reflection of qualitative and quantitative strategies of biochemical adaptations, which aim to compensate lipid metabolism of fish under the different tropho-ecological conditions of habitation in the White Sea.

Acknowledgments: The research was made in the frame of the budgetary theme No. 0221-2014-0003 and was supported by RFBR 14-04-00473 (biochemical analysis, fatty acids), RFBR 16-45-100162 (habitats analysis).

Author Contributions: Svetlana A. Murzina, Ziniada A. Nefedova, Svetlana N. Pekkoeva-work and analysis planning, lipid and fatty acids analysis, paper writing; Tatiana R. Ruokolainen-high performance liquid chromatography operations; Pauli O. Ripatti-gas chromatography analysis; Andrey V. Semushin—the fieldwork planning; Nina N. Nemova-the scientific leader and the project supervisor.

Conflicts of Interest: The authors declare no conflicts of interest.

\section{References}

1. Kuznetsov, V.V. The White Sea and Its Biological Features of Flora and Fauna; Academy of USSR: Moscow, Russia, 1960; pp. 57-298.

2. Lapin, Y.E. White Sea herring as a Biological Entity. Laws of Fish Population Dynamics of the White Sea and Its Basin; Nauka: Moscow, Russia, 1966; pp. 5-28.

3. Lapin, Y.E.; Pohilyuk, V.V. Spatial dynamics generations of the White Sea herring Clupea pallasi marisalbi Berg. J. Ichthyol. 1993, 33, 367-371.

4. Galkina, L.A. The Origin and the Locality of the White Sea Herring. VIII Session of the Scientific Council on the Issue of "Biological Resources of the White Sea and the Inland Waters of the European North" (Abstracts); KarRC RAS: Petrozavodsk, Russia, 1969; pp. 207-208. 
5. Dushkina, L.A. The pigmentation of the larvae of sea herring Clupea in the early stages of development in relation to population dynamics. In Biology of the White Sea Herring; Elsevier Applied Science: London, UK, 1975; pp. 227-254.

6. Muhomedyarov, F.B. Migration ways of the small White Sea herring based on their labeling. In Biology White Sea Herring; Elsevier Applied Science: London, UK, 1975; pp. 109-125.

7. Layus, D.L. Population Structure of the White Sea Herring: Data of Karyological Analysis. The Results of Study of the White Sea Herring; ZIN RAS: St. Petersburg, Russia, 1990; pp. 113-125.

8. Vekhov, V.N. Current status of eelgrass in the White Sea. In The White Sea. Biological Resources and Problems of Their Rational Use. Part 1; ZIN RAS: St. Petersburg, Russia, 1995; pp. 176-187.

9. Alimov, A.F. Production Hydrobiology and functioning of ecosystems. In New Ideas in Oceanology; Nauka: Moscow, Russia, 2004; Volume 1, pp. 264-279.

10. Shatunovskiy, M.I. Ecological Features of Metabolism of Marine Fish; Nauka: Moscow, Russia, 1980; p. 288.

11. Gershanowitsch, A.D.; Lapin, V.I.; Shatunovskij, M.I. Specific features of lipid metabolism in fish. Usp. Sovrem. Biol. 1991, 3, 207-219.

12. Pavlov, D.S.; Nefedova, Z.A.; Veselov, A.E.; Nemova, N.N.; Ruokolainen, T.R.; Vasileva, O.B.; Ripatti, P.O. Age dynamics of lipid status of juveniles of Atlantic salmon (Salmo salar L.) from the Varzuga river. J. Ichthyol. 2009, 49, 1073-1080. [CrossRef]

13. Sidorov, V.S. Ecological Biochemistry of Fishes; Nauka: Leningrad, Russia, 1983; p. 240.

14. Hochachka, P.W.; Somero, G.N. Biochemical Adaptation: Mechanism and Process in Physiological Evolution; Oxford University Press: New York, NY, USA, 2002; p. 466.

15. Iverson, S.J. Tracing aquatic food webs using fatty acids: From qualitative indicators to quantitative determination. In Lipids in Aquatic Ecosystems; Arts, M.T., Brett, M.T., Kainz, M.J., Eds.; Springer: New York, NY, USA, 2009; pp. 281-309.

16. Iljash, L.B.; Zitina, L.S.; Fedorov, V.D. Phytoplankton of the White Sea; Janus-K: Moscow, Russia, 2003; pp. 48-154.

17. Primakov, I.M. Morphometry and oceanographic characteristics. In Biological Resources of the White Sea: Study and Use. The Fauna of the Seas; ZIN RAS: St. Petersburg, Russia, 2012; Volume 69, pp. 7-13.

18. Sapozhnikov, V.V.; Arzhanova, N.V.; Mordasova, N.V. Hydrochemical bases productivity. In Biological Resources of the White Sea: Study and Use. The Fauna of the Seas; ZIN RAS: St. Petersburg, Russia, 2012; Volume 69, pp. 13-34.

19. Troshkov, V.A. Zooplankton. In Biological Resources of the White Sea: Study and Use. The Fauna of the Seas; ZIN RAS: St. Petersburg, Russia, 2012; Volume 69, pp. 67-87.

20. Karagezyan, K. The Phospholipids and Their Role in the Life of the Organism; Yerevan State University: Yerevan, Armenia, 1977; pp. 25-29.

21. Nefedova, Z.A.; Ruokolainen, T.R.; Vasilyev, O.B.; Nemova, N.N.; Kashulin, N.A. Some lipid metabolism of different age females of Coregonus albula from the lake. Syamozero (Karelia) and Lake. Kovdor (Murmansk region) during feeding. J. Ichthyol. 2005, 45, 689-694.

22. Murzina, S.A. The Role of Lipids and Their Fatty Acid Components in the Biochemical Adaptations of the Daubed Shanny Leptoclinus maculatus F. from the North-Western Coastal Waters of Spitsbergen. Ph.D. Thesis, Karelian State Pedagogical Academy, Petrozavodsk, Russia, 2010; p. 184.

23. Dyatlovitskaya, E.V.; Bezuglov, V.V. Lipids like bioeffectors. Introduction. Biochemistry 1998, 63, 67-74.

24. Kolomiytseva, I.K.; Perepelkina, N.I.; Patrushev, I.V.; Popov, V.I. The role of lipids in the endoplasmic reticulum and assembly dictyosomes of the neuronal cells of the cells of the cerebral cortex Yakut gopher Citellus undulates during hibernation. Biochemistry 2003, 68, 954-967.

25. Christie, W.W. Available online: http://lipidlibrary.aocs.org/Primer/content.cfm?ItemNumber=39292\& navItemNumber=19204 (accessed on 15 May 2016).

26. Lopuhin, Y.M.; Archakov, A.I.; Vladimirov, Y.A.; Kogan, E.M. Cholesterinoz; Medicine: Moscow, Russia, 1985; p. 350.

27. Nemova, N.N.; Nefedova, Z.A.; Murzina, S.A.; Veselov, A.E.; Ripatti, P.O.; Pavlov, D.S. The effect of environmental conditions on the dynamics of fatty acids in juveniles of the Atlantic salmon (Salmo salar L.). Russ. J. Ecol. 2015, 46, 267-271. [CrossRef] 
28. Yanes-Roca, C.; Rhody, N.; Nystrom, M.; Main, K.L. Effects of fatty acid composition and spawning season patterns on egg quality and larval survival in common snook (Centropomus undecimalis). Aquaculture 2009, 287, 335-340. [CrossRef]

29. Kreps, E.M. Lipids of Cell Membrane. Evolution of Brain Lipids; Nauka: Leningrad, Russia, 1981; p. 339.

30. Viso, A.C.; Marty, J.C. Fatty acids from 28 marine microalgae. Phytochemistry 1993, 34, 1521-1533. [CrossRef]

31. Viron, C.; Saunois, A.; Andre, P.; Perly, B.; Laffose, M. Isolation and identification of unsaturated fatty acid methyl esters from marinew micro-algae. Anal. Chim. Acta 2000, 409, 257-266. [CrossRef]

32. Graeve, M.; Lundberg, M.; Boer, M.; Kattner, G.; Hop, H.; Falk-Petersen, S. The fate of dietary lipids in the Arctic ctenophore Mertensia ovum (Fabricius 1780). Mar. Biol. 2008, 153, 643-651. [CrossRef]

33. Berger, V.J. Production Potential of the White Sea; ZIN RAS: St. Petersburg, Russia, 2007; pp. 66-131.

34. Falk-Petersen, S.; Hopkins, C.C.E.; Sargent, J.R. Trophic relationships in the pelagic, arctic food web. In Proceedings of the 24th European Marine Biology Symposium, Trondheim, Norway, 12-16 May 1990; pp. 315-333.

35. Primakov, I.M.; Berger, V.Y. Production of planktonic crustaceans in the White Sea. Mar. Biol. 2007, 33, 356-360. [CrossRef]

36. Primakov, I.M.; Kuznetsov, E.A. The study, sustainable use and protection of natural resources of the White Sea. Articles XI All-Russian conference with international participation. In Spatial Distribution of Summer Zooplankton of the White Sea and South-Eastern Part of the Barents Sea; ZIN RAS: St. Petersburg, Russia, 2010; pp. 142-143.

37. Kalchenko, E.I.; Videnskaya, T.L.; Yurjeva, M.I. Feeding and fatty acid content of wild and captured juveniles of dog-salmon during keeping in river fishponds. In Proceedings of the International Conference Modern Problems of Physiology and Biochemistry of Aquatic Organisms, Petrozavodsk, Russia, 6-9 September 2004; KarRC RAS: Petrozavodsk, Russia, 2004; p. 58.

38. Sergeeva, M.G.; Varfolomeeva, A.T. The Cascade of Arachidonic Acid; Narodnoe Obrazovanie: Miscow, Russia, 2006; pp. 21-38.

39. Boldyrev, A.A.; Kaivarainen, E.I.; Ilykha, V.A. Biomembranology; KarRC RAS: Petrozavodsk, Russia, 2006; pp. 24-102.

40. Semushin, A.V.; Sherstkov, V.S.; Rukhlova, V.A. Diversity of fish species in the trawl catches in the southeastern Barents Sea in 1980-2008. J. Ichthyol. 2011, 51, 717-737. [CrossRef]

41. Folch, J.; Lees, M.; Sloane Stanley, G.H. A simple method for the isolation and purification of total lipids from animal tissue. J. Biol. Chem. 1957, 226, 497-509. [PubMed]

42. Walsh, D.E.; Banasik, O.J.; Gilles, K.A. Thin-layer chromatographic separation and colorimetric analysis of barley or malt lipid classes and their fatty acids. J. Chromatogr. 1965, 17, 278-287. [CrossRef]

43. Sidorov, V.S.; Lisenko, E.I.; Bolgova, O.M.; Nefedova, Z.A. Lipids of Fish. I. Methods of Analyses. The Tissues Specificity of Vebdace Lipids (Coregonus albula L.). In Salmonidae of Karelia. Issue 1 Ecology Parasites Biochemistry; Potapova, O.I., Smirnov, Y.A., Eds.; Karelian Branch of the USSR Academy of Sciences, Institute of Biology: Petrozavodsk, Russia, 1972; pp. 150-161.

44. Engelbrecht, F.M.; Mari, F.; Anderson, J.T. Cholesterol determination in serum. A rapid direction method. S. Afr. Med. J. 1974, 48, 250-356. [PubMed]

45. Arduini, A. High performance liquid chromatography of long-chain acylcarnitine and phospholipids in fatty acid turnover studies. J. Lipid Res. 1996, 37, 684-689. [PubMed]

46. Jamieson, G.R. GLC-identification techniques for longchain unsaturated fatty acids. J. Chromatogr. Sci. 1975, 13, 491-497. [CrossRef] [PubMed]

47. Korosov, A.V.; Gorbach, V.V. Computer Processing of Biological Data; KarRC RAS: Petrozavodsk, Russia, 2007 ; p. 76.

48. Zabetakis, I. Marine Oils and Diseases in Marine Oils (from Sea to Pharmaceuticals); NOVA Science Publishers: New, York, NY, USA, 2015; pp. 83-90.

49. Morphis, G.; Kyriazopoulou, A.; Nasopoulou, C.; Sioriki, E.; Demopoulos, C.A.; Zabetakis, I. Assessment of the in Vitro antithrombotic properties of sardine (Sardina pilchardus) fillet lipids and cod liver oil. Fishes 2016, 1, 1-15. [CrossRef]

(C) 2016 by the authors; licensee MDPI, Basel, Switzerland. This article is an open access article distributed under the terms and conditions of the Creative Commons Attribution (CC-BY) license (http://creativecommons.org/licenses/by/4.0/). 